\title{
Hemagglutination Inhibition Assay
}

National Cancer Institute

\section{Source}

National Cancer Institute. Hemagglutination Inhibition Assay. NCI Thesaurus. Code C120688.

An in vitro assay that is used to determine whether antibodies present in serum samples will prevent hemagg lutination in a cell culture plate containing red blood cells and influenza virus. 